\title{
Çay Tarımı Yapılan Topraklara Yönelik Faktör Analizi ve Jeoistatistik Uygulamaları: Rize İli Örneği
}

\author{
M. Arif ÖZYAZICI $\quad$ Mustafa SAĞLAM ${ }^{2 *}$ Orhan DENGiZ2 $\quad$ Aylin ERKOÇAK ${ }^{3}$ \\ 'Siirt Üniversitesi, Ziraat Fakültesi, Tarla Bitkileri Bölümü, Siirt \\ ${ }^{2}$ Ondokuz Mayıs Üniversitesi, Ziraat Fakültesi, Toprak Bilimi ve Bitki Besleme Bölümü, Samsun \\ ${ }^{3}$ Karadeniz Tarımsal Araștırma Enstitüsü, Samsun
}

\begin{abstract}
*Sorumlu yazar e-posta (Corresponding author e-mail): mustafa.saglam@omu.edu.tr
Geliș tarihi (Received) : 08.10.2013

Kabul tarihi (Accepted) : 26.11.2013
\end{abstract}

\section{Öz}

Bazı fiziksel ve kimyasal toprak özelliklerinin faktör analiziyle değerlendirildiği bu çalıșmada, Rize ilinde çay tarımı yapılan alanlarda fiziksel ve kimsayasal toprak özellikleriyle ilișkili 5 adet faktör belirlenmiș ve bu faktörler toprak özelliklerinin alan içerisindeki değișkenliğinin \% 75.63'ünü açıklamıșlar. Belirlenen yeni değișkenler bazik katyonlar, mikroelement, tekstür, mineralizasyon ve gübreleme isimleriyle tanımlanmıștır. Bazik katyonlar toplam değișkenliğin \% 18.31'ini açıklayarak yeni değișkenler içerisindeki en önemli değișken olurken, gübreleme değișkeni toplam değișkenliği en az açıklayan değișken olmuștur. Belirlenen değișkenlerin çalıșma alanındaki dağım desenlerini gösteren krigleme haritaları jeoistatistik yöntemiyle hazırlamıștır. Krigleme haritaları bazik katyonlar ve mikroelement faktörlerinin en yüksek değerlerini sahilden uzak yüksek eğime ve rakıma sahip alanlarda aldığını ortaya koyarken diğer faktörler en yüksek değerlerini sahile yakın kesimlerde almıștır. Özellikle sahil kesimlerindeki gübreleme faktörüne ait yüksek değerler bu bölgelerdeki topraklar üzerinde insan etkisinin daha fazla olduğunu ortaya koymaktadır.

Anahtar Kelimeler: Çay alanları, asidik toprak, faktör analizi, jeoistatistik.

\section{Factor Analysis and Geostatistic Applications for Tea Cultivated Soils Case Study; Rize Province}

\begin{abstract}
Five factors related with physical and chemical soil properties in tea cultivated areas of Rize province were determined some physical and chemical soil properties were evaluated with factor analysis in this study. These factors explained about $75.63 \%$ of total variables in soil properties of the area. Determined new variables were called as basic cations, microelement, texture, mineralization and fertilization. Basic cations that explained $18.31 \%$ of total variables is the most important variable in new variables wheras, it was found that fertilizer variables is the lowest explain for total variables. Spatial distribution maps of the determined variables in the study area was prepared using geostastistic methods. Kriging maps show that the highest values of the basic cations and microelements were located in high and steep sloped lands whereas, it was found that the highest values of other factors distributed in near the coast area. Especially, high values of the fertilizer distibuted on flat-delta area showed under more human activites.
\end{abstract}

Key Words: Tea areas, acidic soil, factor analysis, geostatistic 


\section{Giriș}

Türkiye'nin kuzeydoğusunda yer alan Rize ili; Doğu Karadeniz bölgesinin en yüksek kesiminde $40^{\circ} 20^{\prime}$ doğu ve $41^{\circ} 20^{\prime}$ kuzey paralelleri arasında, 3920 km²'lik yüzölçümü ile ülke topraklarının \% 5'ini kaplamaktadır. Çok engebeli ve dağlık bir arazi yapısına sahip olan ilin kıyı șeridinin uzunluğu $80 \mathrm{~km}$, genișliği ise 20-150 km arasında değișirken, yüksek kıyılardan olușan ve genellikle sade bir görünüșe sahip olan kıyı șeridinde, akarsuların tașıdığı alüvyonlarla olușan düzlükler yer almaktadır.

Toplam arazi varlığı 359991 ha olan Rize ilinde tarım alanları, toplam arazi varlığının yaklașık \% 16'sını oluștururken, çayır ve mera alanları $\% 12,59$ 'unu, orman ve fundalık araziler \% 44'ünü, tarım dıșı ve yerleșim alanları ise $\%$ 28,21'ini olușturmaktadır (Anonim 2012). Tarım alanlarının \% 98,5'i tarla arazisi, \% 0,7'si nadas, \% 0,8'i de meyve-bağ arazisi șeklinde kullanılmaktadır (Anonim 2011). Verimlilik açısından oldukça fakir topraklara sahip olan ilde, tarım alanlarının yalnızca \% 13,5'i arazi kullanım kabiliyet sınıfı yönünden ilk dört sınıfta yer alırken, büyük bir kısmı tarıma elverișli olmayan V., VI., VII. ve VIII. sınıf arazilerden olușmaktadır. Bu nedenle, tarım arazilerinin \% 70'inden fazlası su erozyonu, yetersiz toprak derinliği ve yetersiz drenajdan kaynaklanan sorunlarla karșı karșıya bulunmaktadır. Yine ildeki diğer arazi kullanımları arasında bulunan ve çok küçük bir kısmı (yaklașık \% 1) sulak alan sınıfına giren arazilerde yayılım göstermesine karșın büyük çoğunluğu yüksek dağlarda bulunan çayır ve mera alanlarında, yetersiz toprak derinliği ve drenaj ile kontrolsüz ve așırı otlatma sonucu artan erozyona bağlı sorunlar bulunurken, yaklașık \% 85'i geniș yapraklı ve karıșık çam ormanlarından olușan ormanlık alanlarda da, arazi eğiminin çok dik olması sonucu meydana gelen toprak erozyonu, söz konusu alanlar için en önemli problemlerden biri olarak görünmektedir.

Doğu Karadeniz bölgesindeki iklimsel ve topografik özellikler nedeniyle tarımsal üretimin oldukça sınırlı olduğu Rize ilinde, tarım genellikle düzlük arazilerde ve kıyı kesimlerinde yapılırken, mevcut arazi kalitesinin düșük olmasıda hem ildeki tarımsal faaliyetlerin çok sınırlı miktarda kalmasını hemde tarımın ancak özel tarımsal teknikler kullanılarak yapılmasını zorunlu kılmaktadır. İldeki tarım alanlarının büyük kısmında çay ve fındık tarımı yapılmaktadır. Bu nedenle Rize ilinin tarım arazilerinin büyük bir kısmı (\% 85) çay ve fındık tarımı için ayrılmıș durumdadır. Türkiye'de çay tarımı Doğu Karadeniz Bölgesi'nde Gürcistan sınırından bașlayarak Ordu ilinin Fatsa ilçesine kadar olan kușakta yapılmaktadır. Bu bölgeler içerisinde Rize ili, çay yetiștirilmesi bakımından en elverișli ve birinci derecede çay üretimine uygun verimli alanları olușturmaktadır. Bu sebeple çay, ilin en önemli tarımsal ürünü olup ülke üretiminin yaklașık \% 60'ını karșılamaktadır.

Çay bitkisinin yetișmesine etki yapan en önemli etkenler iklim ve toprak özellikleridir. Yıllık sıcaklık ortalamasının $14{ }^{\circ} \mathrm{C}$ 'nin altına düșmemesi, toplam yıllık yağıșın 2000 mm'den az olmaması ve aylara göre dağılımının düzenli olması, bağıl nem oranının ise en az \% 70 olması, çay bitkisinin normal gelișimi için gerekli olan iklim koșullarıdır. Toprak özellikleri yönünden asit reaksiyonlu toprakları seven çay bitkisi, genelde 4,5-6 arasında değișen pH'ya sahip ve aktif kireç miktarı düșük topraklarda optimum gelișme gösterir (Gökhale, 1952; Sharma ve Ranhanathan, 1985). Toprak pH'sının asit ya da alkalin yöndeki değișimlerinden olumsuz yönde etkilenirken, toprak pH'sı 4'ün altına düștüğünde istenen verim ve kalitede ürün alınamaz hale gelir (Tekeli, 1962; Eden, 1976; Tekeli, 1976; Kacar, 1984). Toprak tekstürü açısından kumdan killi tekstüre kadar değișen topraklarda yetișebilen çay bitkisi, toprağın derin ve bitki besin madelerince zengin olmasını isterken ağır killi, kireçli ve taban suyu yüksek alanlarda ise bitki gelișmi olumsuz yönde etkilenmeye bașlar. Bu nedenle çay yetiștiriciliği yapılan düz arazilerin organik maddece zengin ve geçirgenliğinin yüksek olması istenirken, eğimli arazilerde de eğimin \% 50'den fazla olmaması ve eğimin etkilerini azaltmak için de setleme ile teraslama yapılması tavsiye edilir.

Bu çalıșmayla Rize ilinde çay tarımı yapılan alanlardan alınan toprak örneklerine ilișkin bazı fiziksel ve kimyasal özellikler kullanılarak çay üretimi yapılan topraklara yönelik minimum veri setinin olușturulması amaçlanmıștır. Toprak özellikleri özellikle toprak olușum faktörleriyle birlikte yönetim uygulamalarına ve arazi kullanımlarına bağlı olarak zamansal ve konumsal olarak önemli değișkenlikler gösterir. Ayrıca, 
toprakların fiziksel ve kimyasal özellikleri ile ilgili bilgiler, toprakta gerçekleșen ayrıșma, erozyon, yüzey akıș ve yeraltı suyunun depolanması gibi fiziksel ve kimyasal süreçlerin anlașılması ve değerlendirilmesi için de önemlidir (Daniels ve Hammer, 1992). Yukarıda genel olarak bahsedilen heterojenlik kaynakları nedeniyle her bir toprak özelliği, aynı anda birbiri ile ilișkili olan bir veya birden fazla değișken tarafından etkilenebilirler. Ayrıca, gerçek hayatta ve modern bilimsel çalıșmalarda temel alınan birim ve değișken sayısı birden fazla olup, bu birim ve değișkenlerin de karșilıklı etkileșimleri söz konusudur. Değișkenler arasındaki ilișkileri dikkate almadan birden fazla değișkenin ayrı ayrı ele alınarak analiz edilmesi, önemli bilgi kayıplarının yașanmasına bazen de gerçek bilimsel durumların tam olarak açıklanamamasına neden olmaktadır. Yașanan bu bilgi kayıplarının en aza indirilmesi ve birbiriyle az veya çok ilișkili olan çok sayıda değișkenin sağıklı bir șekilde değerlendirilebilmesi için "Çok Değișkenli Analiz Yöntemleri" geliștirilmiștir. Çok değișkenli istatistiksel yaklașımı tek değișkenli istatistiksel analizlerden üstün kılan temel özellik, tek değișkenli istatistiksel analizlerde veri olarak kabul edilen birçok faktörün çok değișkenli analizlerde birer değișken olarak sisteme dâhil edilebilmesidir (Ünlükaptan, 2008). Bu çalıșmada da Rize ilinde çay üretimi yapılan topraklara ilișkin birbiri ile ilișkili çok sayıdaki fiziksel ve kimyasal toprak özelliğinin çok değișkenli analiz yöntemlerinden faktör analizi ile değerlendirerek çay üretim alanlarına yönelik minimum veri setinin olușturulması ve olușturulan minimum veri setinin konumsal değișkenliğinin haritalanması amaçlanmıștır.

\section{MATERYAL ve YÖNTEM}

\section{Calıșma Alanının Tanımlanması}

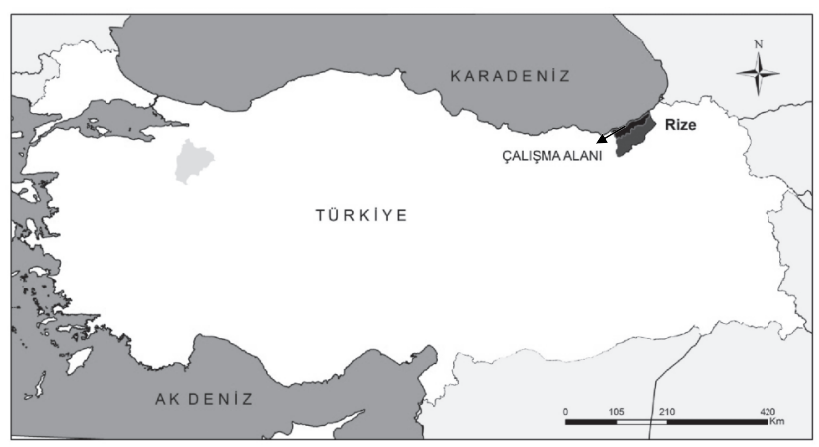

Șekil 1. Çalıșma alanı lokasyon haritası

Figure 1. The location map of the study area
Rize ili kuzeyden Karadeniz, doğudan Artvin, güneyden Erzurum, güneybatıdan Bayburt ve batıdan Trabzon illeri ile çevrilidir (Șekil 1).

Doğu Karadeniz kıyı sıradağları yayının kuzey yamacında yer alan Rize ili toprakları dağlık ve engebelidir. 80 km uzunluğundaki kıyı șeridinin genișliği akarsu vadileri dıșında ortalama 20-150 m arasında değișmektedir. Çok sayıda akarsu tarafından kesilen bu șeridin en geniș düzlüklerini taban seviyesi ovaları olușturmaktadır. Tümüyle akarsuların getirdiği alüvyonlardan olușan bu düzlükler, akarsuların denize kavuștuğu noktadan itibaren içeriye doğru 500-600 metreye kadar taban seviyesi ovası șeklinde, 9-10 km'ye kadar da taraça düzlükleri șeklinde uzanmaktadır. Bu düzlüklerin kıyı boyunca olan genișlikleri ise yaklașık olarak $200 \mathrm{~m}$ ile $1000 \mathrm{~m}$ arasında değișmekte olup, hemen tamamı yerleșik alanlardır. Bunlardan en geniș olanı Ardeșen ilçe merkezinin yerleșim alanını olușturan Fırtına Deresi'nin ovasıdır. Topoğrafya kıyı düzlüğünün hemen gerisinde arızalanmakta ve yükselti birdenbire 150-200 metreyi bulmaktadır. Buradan itibaren arazi, giderek daralan akarsu vadileri tarafından derin bir șekilde yarılmaktadır. Yaklașık 2000 m yükseklikten bașlayan yüksek dağlık saha ve buzul topoğrafyasının 3000-3200 m yüksekliğe kadar olan kısımlarında topoğrafya basık sırtlar, dik yamaçlı " "U" profilli vadilerden olușmaktadır. Bu alanda çok sayıda küçük boyutlu buz yalağı ve moren set gölleri mevcuttur. Yüksekliği 3000 m'yi așan kısımlar ise Rize'nin en sarp ve en arızalı kesimini olușturmaktadır. Üzerinde hâlâ buzul bulunan ve Rize topraklarının en yüksek noktası olan Kaçkar Tepesi (3937 m) ile Verçenik (Üçdoruk) Tepesi (3709 m)'nin yarattığı arızalı topoğrafya Fındıklı ilçe merkezinin güneyinden itibaren sarplığını ve yüksekliğini kaybetmektedir (Anonim 2013). Rize'nin en önemli iklimsel özelliği her mevsim yağıșlı olmasıdır. Yazlar serin, kıșlar ise ılıman geçmektedir (Çizelge 1). Türkiye'nin en çok yağıș alan ili Rize'dir. Rize'de iki farklı iklim tipi görülmektedir. Kıyı kısmında ılık ve yağıșlı bir iklim tipi yaygınken, iç kesimlerde karasal iklim özelliği hâkimdir, ancak diğer illere oranla, Rize'de iç kesimler de önemli ölçüde yağıș almaktadır. Kıyı kesimde yazlar ılık, kıșlar ise serin geçmektedir (Anonim, 2012). 
Çizelge 1. Araștırma alanında uzun yıllar (1970-2011) içinde gerçekleșen önemli bazı meteorolojik elemanlara ait ortalama değerler

Table 1. The average values belonging to some important meteorological elements that took place within many years in the study area (1970-2011)

Ocak Șubat Mart Nisan Mayıs Haz. Tem. Ağus. Eylül Ekim Kasım Aralık

\begin{tabular}{|c|c|c|c|c|c|c|c|c|c|c|c|c|}
\hline Ortalama SiC. $\left({ }^{\circ} \mathrm{C}\right)$ & 6,4 & 6,4 & 8,0 & 11,7 & 16,0 & 20,4 & 23,0 & 23,2 & 20,0 & 16,0 & 11,4 & 8,2 \\
\hline $\begin{array}{l}\text { Ort. En Yüksek } \\
\text { SiC. }\left({ }^{\circ} \mathrm{C}\right)\end{array}$ & 10,5 & 10,7 & 12,1 & 15,5 & 19,4 & 23,8 & 26,3 & 26,7 & 24,2 & 20,4 & 16,0 & 12,5 \\
\hline $\begin{array}{l}\text { Ort. En Düșük } \\
\text { Sic. }\left({ }^{\circ} \mathrm{C}\right)\end{array}$ & 3,5 & 3,4 & 4,9 & 8,4 & 12,5 & 16,6 & 19,7 & 20,1 & 16,9 & 13,0 & 8,3 & 5,2 \\
\hline $\begin{array}{l}\text { Ort. Güneșlenme } \\
\text { Süresi (saat) }\end{array}$ & 2,1 & 2,6 & 3,4 & 4,3 & 5,4 & 6,4 & 5,2 & 5,0 & 5,0 & 4,0 & 2,5 & 2,6 \\
\hline $\begin{array}{l}\text { Ort.Yağısșı Gün } \\
\text { Sayısı } \\
\text { Aylık Toplam }\end{array}$ & 15,1 & 14,3 & 15,8 & 15,5 & 15,1 & 14,6 & 14,4 & 15,2 & 15,3 & 16,2 & 14,7 & 15,3 \\
\hline $\begin{array}{l}\text { Yağıș Miktarı Ort. } \\
\left(\mathrm{kg} / \mathrm{m}^{2}\right)\end{array}$ & 212,0 & 178,1 & 144,1 & 93,9 & 99,1 & 138,6 & 148,9 & 182,1 & 251,8 & 305,1 & 256,0 & 243,2 \\
\hline
\end{tabular}

\section{Toprak Örneklemesi ve Analizler}

Rize ilindeki çay üretim alanlarında yürütülen bu çalıșmada örnekleme yerleri, grid sistemine göre örnek noktaları arasındaki mesafe 2500 m olacak șekilde küresel konumla aleti (GPS) yardımıyla belirlenmiș ve sonrasında toprak örneklemesi, 0-30 $\mathrm{cm}$ derinlikten bozulmuș toprak örnekleme yöntemine göre yapılmıștır (Șekil 2).

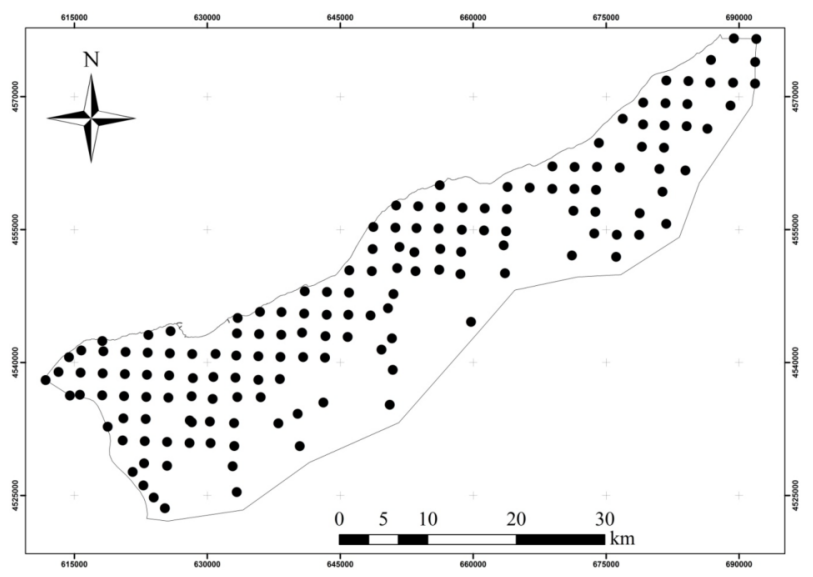

Sekil 2. Toprak örnekleme deseni ve örnek yerleri

Figure 2. Soil sampling pattern and sample locations

Alınan toprak örneklerinde Bouyoucos hidrometre yöntemiyle tekstür (Gee and Bauder, 1986), Scheibler kalsimetresi ile volümetrik olarak kireç (Nelson, 1982), Smith-Weldon yöntemiyle organik madde (Nelson and Sommers, 1982), 1:2'lik toprak-su karıșımında pH (Hendershot et al.
1993) ve elektriksel iletkenlik (Rhoades 1986), kjeldahl yöntemine göre toplam azot (N) (Bremner and Mulvaley, 1982), Bray and Kurtz No.1 yöntemine göre yarayıșlı fosfor (P) (Bray and Kurtz, 1945), ekstrakte edilebilir potasyum (K), kalsiyum (Ca), magnezyum (Mg) ve sodyum (Na) (Soil Survey Staff, 1992), DTPA ile ekstraktraksiyon sonrasında elde edilen çözeltinin atomik adsorbsiyon spektrofotometresinde okunmasıyla yarayıșlı demir (Fe), bakır (Cu), çinko (Zn), mangan (Mn) (Anonymous, 1990) ve azometin-H yöntemine göre de yarayıșlı bor (B) (Wolf, 1971) analizleri yapılmıștır.

\section{Çok Değișkenli İstatistik ve Jeoistatistik Analizleri}

Çalıșmada incelenen 18 adet fiziksel ve kimyasal toprak özelliği ile ilișkili yeni değișkenlere sahip minimum veri setinin olușturulmasında, çok değișkenli istatistik yöntemlerinden faktör analizi kullanııırken; faktör olarak isimlendirilen minimum veri setindeki değișkenlerin uzaysal dağılım haritaları ise jeoistatistik analiz yöntemi kullanılarak hazırlanmıștır.

Faktör analizi, boyut indirgeme ve bağımlıık yapısını yok etme amacını gerçekleștirmekle birlikte, p değișkenli bir olayda birbiri ile ilgili değișkenleri bir araya getirerek, az sayıda yeni (ortak) ilișkisiz değișken bulmayı amaçlar (Tatıdil, 2002). Faktör analizinde değișken olarak kullanılan 
toprak özelliklerinin farklı birimlere sahip olması nedeniyle birimlerin etkilerini elemine etmek için faktör analizinde, ölçülen toprak özelliklerinin ortalama ve standart sapma değerleri kullanılarak ortalaması 0, standart sapması 1 olacak șekilde yeniden üretilen standartlaștırılmıș değerleri kullanılmıștır. Analize dahil edilecek değișkenler, korelasyon matriksindeki katsayılar ve oransal etken varyansları dikate alınarak belirlenmiș, buna göre çalıșmada incelenen özellikler arasında olmalarına karșın kil, kireç, EC, ekstrakte edilebilir $\mathrm{Na}, \mathrm{B}$ ve Mn faktör analizine değișken olarak dahil edilmemiștir. Faktör analizi sonucunda öz değerleri $\geq 1$ olan gruplar faktör olarak kabul edilirken, faktör seçiminde kritik faktör yükü 0.5 olarak alınmıștır.

Belirlenen faktörlerin alan içerisindeki uzaysal dağılımları ise jeoistatistiksel analiz yöntemi kullanılarak modellenmiș ve haritalandırılmıștır. Jeoistatistiksel analiz yönteminde faktörlerin uzaysal değișkenlik bilgisini ortaya koymak amacıyla, Eșitlik 1. kullanılarak, her bir faktöre ait semivariogram modelleri tahmin edilmiștir.

$$
\gamma(h)=\frac{1}{2 N} \sum_{i=1}^{N}\left(z\left(x_{i}\right)-z\left(x_{i}+h\right)\right)^{2}
$$

Burada;

h : ayırma uzaklığı (lag)

$\gamma(\mathrm{h}) \quad:$ h uzaklığı için semivaryans

z (xi) : x noktasında ölçülmüș örnek değeri

$z(x i+h): x+h$ noktasında ölçülmüș örnek değeri

$\mathrm{N} \quad$ : h ayırma uzaklığı için çiftlerin toplam sayısını tanımlamaktadır.

Faktörlere ait en uygun semivariogram modeline yöne bağı değișimler, belirleme katsayısı, hata kareler toplamı ve çapraz doğrulamada regresyon katsayısı kontrol edilerek karar verilmiștir. Daha sonra tahmin edilen semivariogram modelleri kullanılarak krigleme yöntemiyle faktörlerin alansal değișkenlikleri haritalanmıștır. Yapılan tüm çok değișkenli istatistik ve jeoisatistik analizleri sırasında SPSS 17.0, GS+ 7.0 ve ArcMap 9.3 programları kullanılmıștır.

\section{BULGULAR ve TARTIȘMA}

Çalıșmada incelenen fiziksel ve kimyasal toprak özelliklerine ait tanımlayıcı istatistikler Çizelge 2'de verilmiștir. Toprak özellikleri değișkenlik katsayısı açısından Wilding (1985)'in yaptığı sınıflandırmaya göre incelendiğinde, çoğu toprak özelliğinin çalıșma alanı içerisindeki değișkenliğinin yüksek olduğu görülmektedir. Ekstrakte edilebilir Ca, Mg, $\mathrm{Cu}, \mathrm{Zn}$ ve yarayıșlı P en yüksek değișkenliğe sahip özellikler olarak gözlenirken, pH değișkenliği düșük, kireç, kum ve silt ise değișkenliği orta sınıfında gözlenen fiziksel ve kimyasal toprak özellikleridir. İncelenen özelliklerin çarpıklık katsayılarına bakıldığında ise kum, silt, organik madde, ekstrakte edilebilir Fe, Na gibi özelliklerin normal dağılım sergilediği (Webster 2001), hafif sola çarpık bir dağılım sergileyen kireç dıșındaki diğer tüm özelliklerin ise ortalamanın üzerinde değerler alarak sağa çarpık dağılımlar sergilediği görülmektedir (Çizelge 2).

Toprak özellikleri arasındaki korelasyon ilișkileri Çizelge 3'de verilmiștir. İncelenen 18 adet toprak özelliği arasındaki 171 korelasyon ilișkisinden 52 adeti istatistiksel olarak anlamlı $(\rho<0,01$ ve $p<0,05)$ bulunurken, en güçlü ve en zayıf korelasyon ilișkileri sırasıyla kum ile silt $(-0.78 ; p<0,01)$ ve $\mathrm{pH}$ ile ekstrakte edilebilir $\mathrm{Mn}(0.16 ; p<0,05)$, ekstrakte edilebilir Ca ile ekstrakte edilebilir Zn 10.16; $p<0,05)$, ekstrakte edilebilir B ile ekstrakte edilebilir Mn (-0.16; $p<0,05)$ arasında bulunmuștur (Çizelge 3). Cengiz ve Kılınç (2007), faktör analizinde normallik, çoklu bağlantı ve doğrusallık gibi klasik varsayımların sağlanmasının, değișkenler arasındaki korelasyonlarda düșüșe sebep olduğunu bildirirken, değișkenler arasında sadece türetilecek faktörlerin anlamlılığı test edilecekse, normallik varsayımının aranmasının gerektiğini ifade etmektedir. Bunun yanında Hair et al. (1998)'da, faktör analizinde değișkenler arasındaki iç ilișkiler belirlendiği için, belirli düzeyde çoklu doğrusal bağlantının olması gerektiğini ve değișkenler arasındaki korelasyonların 0,30'dan büyük olmasının faktör analizinin uygulanabilmesi için beklenen bir durum olduğunu belirterek, korelasyon katsayıları 30'dan büyük olmayan değișkenlerin büyük bir olasılıkla faktör analizinden çıkartılmasının uygun olacağını bildirmektedir. Yine benzer șekilde Kalaycı (2010)'da, faktör analizinde korelasyon matriksi için istatistiksel temellerin yanında faktör analizinin uygulanabilirliliğini kanıtlamak için korelasyon matrisinin yeteri kadar anlamlı korelasyonlara sahip olması gerektiğini, çünkü değișkenler arasındaki korelasyonlar ne kadar yüksek ise değișkenlerin ortak faktörler yaratma olasılıklarının o kadar yüksek olduğunu 
Çizelge 2. Toprak özelliklerine ait tanımlayıcı istatistikler

Table 2. The descriptive statistics for soil properties

\begin{tabular}{lccccccccc}
\hline Toprak & \multirow{2}{*}{ Örimi } & Ortalama & En Küçük & En Büyük & $\begin{array}{c}\text { Standard } \\
\text { Sapma }\end{array}$ & $\begin{array}{c}\text { D.K., } \\
\%\end{array}$ & Carpıklık & Basıklık & $n$ \\
\hline Kum & $\%$ & 49,24 & 16,28 & 76,84 & 12,26 & 24,89 & $-0,07$ & $-0,34$ & 155 \\
Kil & $\%$ & 17,91 & 6,05 & 46,01 & 7,67 & 42,83 & 1,10 & 1,56 & 155 \\
Silt & $\%$ & 32,85 & 8,48 & 60,55 & 9,46 & 28,79 & 0,05 & $-0,06$ & 155 \\
pH & & 3,72 & 3,14 & 5,88 & 0,41 & 10,92 & 1,95 & 6,78 & 155 \\
EC & dS m${ }^{-1}$ & 0,14 & 0,02 & 0,86 & 0,12 & 84,82 & 2,70 & 10,99 & 155 \\
Kireç & $\%$ & 0,46 & 0,10 & 0,60 & 0,10 & 21,01 & $-0,64$ & 2,08 & 155 \\
OM & $\%$ & 5,43 & 0,47 & 9,76 & 2,36 & 43,42 & $-0,15$ & $-0,81$ & 155 \\
YP & $\mathrm{mg} \mathrm{kg}^{-1}$ & 37,73 & 1,50 & 165,50 & 38,03 & 100,78 & 1,35 & 1,28 & 155 \\
TN & $\%$ & 0,27 & 0,05 & 0,59 & 0,12 & 44,17 & 0,76 & 0,24 & 155 \\
Ek.K & $\mathrm{mg} \mathrm{kg}^{-1}$ & 172,20 & 30,98 & 666,00 & 116,75 & 67,79 & 1,75 & 2,40 & 155 \\
Ek.Ca & $\mathrm{mg} \mathrm{kg}^{-1}$ & 1092,10 & 95,00 & 5984,00 & 1265,03 & 115,83 & 1,71 & 2,36 & 155 \\
Ek.Mg & $\mathrm{mg} \mathrm{kg}^{-1}$ & 202,77 & 33,00 & 949,00 & 223,16 & 110,06 & 1,82 & 2,52 & 155 \\
Ek.Na & $\mathrm{mg} \mathrm{kg}^{-1}$ & 306,47 & 39,00 & 891,00 & 247,18 & 80,65 & 0,50 & $-1,25$ & 155 \\
Ek.B & $\mathrm{mg} \mathrm{kg}^{-1}$ & 0,81 & 0,17 & 2,79 & 0,49 & 60,35 & 1,85 & 4,28 & 155 \\
Ek.Fe & $\mathrm{mg} \mathrm{kg}^{-1}$ & 47,36 & 1,33 & 117,33 & 31,16 & 65,81 & 0,29 & $-1,22$ & 155 \\
Ek.Cu & $\mathrm{mg} \mathrm{kg}^{-1}$ & 0,82 & 0,04 & 4,40 & 0,89 & 108,39 & 1,74 & 2,74 & 155 \\
Ek.Zn & $\mathrm{mg} \mathrm{kg}^{-1}$ & 1,00 & 0,07 & 4,79 & 1,04 & 103,67 & 2,01 & 3,70 & 155 \\
Ek.Mn & $\mathrm{mg} \mathrm{kg}^{-1}$ & 28,54 & 0,10 & 80,88 & 20,74 & 72,67 & 0,89 & $-0,21$ & 155 \\
\hline
\end{tabular}

EC: Elektriksel Illetkenlik; OM: Organik Madde; YP: Yarayıșlı Fosfor; TN: Toplam Azot; Ek.K: Ekstrakte Edilebilir Potasyum; Ek.Ca: Ekstrakte Edilebilir Kalsiyum; Ek.Mg: Ekstrakte Edilebilir Magnezyum; Ek.Na: Ekstrakte Edilebilir Sodyum; Ek.B: Ekstrakte Edilebilir Bor; Ek.Fe: Ekstrakte Edilebilir Demir; Ek.Cu: Ekstrakte Edilebilir Bakır; Ek.Zn: Ekstrakte Edilebilir Çinko; Ek.Mn: Ekstrakte Edilebilir Mangan; D.K.: Değișkenlik Katsayısı; n: Örnek Sayısı

ifade etmektedir. Bu nedenle faktör analiziyle ilgili birçok bilimsel çalıșmada korelasyon matriksi, veri setinin faktör analizine uygunluğunun değerlendirilmesinde subjektif bir yaklașım olarak yaygın șekilde kullanılmaktadır. Bu çalıșmada faktör analizinin bașarısını yükseltmek için yapılan korelasyon matriksi değerlendirmesinde, diğer fiziksel ve kimyasal toprak özellikleriyle korelasyon ilișkileri düșük bulunan kil, kireç, EC, ekstrakte edilebilir Na ve B faktör analizine değișken olarak dahil edilmemiștir (Çizelge 3).

Kaiser-Mayer-Olkin (KMO) testi de, veri setinin faktör analizine uygunluğunun test edildiği diğer bir değerlendirme șeklidir. Test değerleri 0 ile 1 arasında değișen $\mathrm{KMO}$ testinde, herhangi bir değișkenin diğer değișkenler tarafından hatasız tahmin edilmesi halinde KMO değeri 1'e eșit olurken, değișken çiftleri arasındaki ilișkilerin diğer değișkenler tarafından açıklanamadığı durumlarda ise bu değer 0'a yaklașmaktadır. KMO değerinin 0'a yakın olduğu bu durumlarda tahmin bașarısı düștüğünden faktör analizinin kullanılmaması gerekmektedir (Cengiz ve Kılınç 2007). Rize ilinde çay üretimi yapılan topraklara yönelik minimum veri setinin olușturulmasının amaçlandığı bu çalıșmada, 0,60 olarak hesaplanan KMO değeri, hazırlanan veri setinin faktör analizine orta düzeyde uygun olduğunu ortaya koymuștur (Kalaycı, 2010).

Faktör analizine uygunluğu hem korelasyon matriksi hemde $\mathrm{KMO}$ testi ile değerlendirilen veri setinde yapılan faktör analizi sonrasında öz değerleri $\geq 1$ olan 5 adet faktör belirlenmiștir (Çizelge 4). Faktör seçiminde gösterge olarak kullanılan öz değer, faktörler ile toprak özellikleri arasındaki ilișkiyi değerlendirmede bir kriter olarak kullanılır ve toprak özellikleri öz değerlerinin en yüksek olduğu faktöre atanırlar (Shukla et al., 2006).

Değișkenlere ait toplam varyansın \% 75,63'ünü açıklayan faktörlerin, fiziksel ve kimyasal toprak özelliklerine ilișkin bireysel varyansları açıklama 
Çizelge 3. Toprak özellikleri arasındaki korelasyon ilișkileri

Table 3. The correlation relationships between soil properties

\begin{tabular}{|c|c|c|c|c|c|c|c|c|c|}
\hline & Kum & Kil & Silt & $\mathrm{pH}$ & EC & Kireç & OM & YP & TN \\
\hline$\overline{\text { Kil }}$ & $-0,64 * \star$ & & & & & & & & \\
\hline Silt & $-0,78 * *$ & 0,01 & & & & & & & \\
\hline $\mathrm{pH}$ & $-0,04$ & 0,02 & 0,04 & & & & & & \\
\hline EC & 0,00 & $-0,02$ & 0,02 & 0,07 & & & & & \\
\hline Kireç & $-0,11$ & 0,01 & 0,14 & 0,02 & $-0,02$ & & & & \\
\hline OM & 0,09 & $-0,11$ & $-0,02$ & $-0,12$ & $-0,03$ & $-0,05$ & & & \\
\hline YP & 0,00 & $-0,04$ & 0,04 & $-0,21 * *$ & 0,05 & 0,03 & $-0,03$ & & \\
\hline TN & $0,30 * *$ & $-0,18$ * & $-0,24 * *$ & $-0,16$ & 0,00 & $-0,12$ & $0,45^{* *}$ & $0,17^{*}$ & \\
\hline Ek.K & $-0,05$ & $-0,07$ & 0,12 & 0,14 & $0,29 * \star$ & $0,20 *$ & $-0,08$ & $0,26 * *$ & 0,00 \\
\hline Ek.Ca & 0,03 & 0,02 & $-0,06$ & $0,57 * *$ & $0,22 * *$ & 0,02 & $-0,24 * *$ & $-0,03$ & $-0,26$ ** \\
\hline Ek.Mg & $0,18^{*}$ & $-0,15$ & $-0,11$ & 0,31 * & 0,04 & 0,05 & $-0,18^{*}$ & $-0,11$ & $-0,18^{*}$ \\
\hline Ek.Na & $0,28 * *$ & $-0,04$ & $-0,34 * *$ & $-0,09$ & $-0,09$ & 0,03 & $-0,08$ & 0,06 & 0,16 \\
\hline Ek.B & $-0,11$ & 0,12 & 0,05 & 0,03 & $-0,10$ & $-0,02$ & 0,13 & 0,08 & $-0,03$ \\
\hline Ek.Fe & 0,14 & 0,04 & $-0,21$ ** & $-0,17^{*}$ & 0,00 & $-0,18^{*}$ & 0,06 & $0,32^{* *}$ & $0,25^{* *}$ \\
\hline Ek.Cu & $-0,03$ & 0,02 & 0,02 & $0,18^{*}$ & $-0,01$ & 0,00 & $-0,21$ ** & 0,12 & $-0,10$ \\
\hline Ek.Zn & 0,02 & 0,03 & $-0,04$ & $0,20 *$ & 0,08 & $-0,14$ & $-0,08$ & $0,39 * *$ & $0,17^{*}$ \\
\hline Ek.Mn & 0,00 & 0,00 & 0,00 & $0,16^{*}$ & $0,28^{* *}$ & 0,05 & $-0,22$ ** & 0,05 & $-0,18^{*}$ \\
\hline
\end{tabular}

\begin{tabular}{|c|c|c|c|c|c|c|c|c|}
\hline & Ek.K & Ek.Ca & Ek.Mg & Ek.Na & Ek.B & Ek.Fe & Ek.Cu & Ek.Zn \\
\hline Ek.Ca & $0,32 * *$ & & & & & & & \\
\hline Ek.Mg & 0,12 & $0,60 * *$ & & & & & & \\
\hline Ek.Na & 0,01 & $-0,06$ & $0,22 * *$ & & & & & \\
\hline Ek.B & 0,02 & $-0,06$ & $-0,11$ & $-0,22$ ** & & & & \\
\hline Ek.Fe & $-0,03$ & $-0,02$ & $-0,06$ & $0,22 * *$ & $-0,02$ & & & \\
\hline Ek.Cu & 0,12 & $0,27^{* *}$ & $0,21 * *$ & 0,08 & $-0,07$ & $0,39 * *$ & & \\
\hline Ek.Zn & 0,14 & 0,16 * & 0,05 & 0,09 & 0,03 & $0,52 * *$ & $0,61 * *$ & \\
\hline Ek.Mn & 0,31 ** & 0,31 ** & $0,17^{*}$ & 0,13 & $-0,16^{*}$ & 0,12 & 0,31 ** & $0,41 * *$ \\
\hline
\end{tabular}

Çizelge 4. Faktörlere ait öz değerler ve varyanslar

Table 4. The eigenvalues and variances for factors

\begin{tabular}{lccc}
\hline Faktörler & Özdeğer & Oransal Varyans, \% & Eklemeli Varyans, \% \\
\hline Faktör 1 & 2607 & 18,31 & 18,31 \\
Faktör 2 & 2354 & 17,83 & 36,14 \\
Faktör 3 & 1888 & 15,98 & 52,12 \\
Faktör 4 & 1176 & 12,62 & 64,74 \\
Faktör 5 & 1050 & 10,90 & 75,63 \\
\hline
\end{tabular}

oranları değerlendirildiğinde, seçilen faktörlerin en yüksek kum ve silte ait değișimleri, en düșük ise ekstrakte edilebilir Mg'a ait değișkenlikleri açıklayabildiği görülmektedir (Çizelge 5). Faktör analizinin bu așamasında diğer toprak özellikleriyle 0,30'un üzerinde korelasyonlar göstermesine karșın, seçilen faktörler tarafından açıklanan oransal ortak etken varyans oranı 0,50'nin altında kalan olan ekstrakte edilebilir Mn, faktör analizine değișken olarak dahil edilmemiștir. Bir değișkene ilișkin faktörlerin açıkladıkları ortak varyans (communality), değișkenin faktör yük değerlerinin kareleri toplamına eșittir. Değișkenin ortak varyansının yüksek olması, modele ilișkin açıklanan toplam varyansı artıracağı anlamına gelmektedir. Ortak varyans değeri 0,50'nin altında düștüğünde ilgili değișken faktör analizinden çıkarılarak analizin yeniden yapılması daha uygun olabilir. Șayet ortak varyansı 0,50 değerinin altında olan değișkenler analiz dıșında bırakılırsa hem KMO değeri hem de açıklanan varyans değeri yükselir (Kalaycı 2010). 
C̣izelge 5. Faktörlere ait değișkenler ve açıklanan bireysel varyanslar

Table 5. The variables and explained individual variances for factors

\begin{tabular}{|c|c|c|c|c|c|c|}
\hline $\begin{array}{l}\text { Toprak } \\
\text { Özellikleri }\end{array}$ & F1 & $\mathrm{F} 2$ & F3 & F4 & F5 & $\begin{array}{c}\text { Oransal Ortak } \\
\text { Etken Varyansları }\end{array}$ \\
\hline Ek.Ca & 0,84 & & & & & 0,79 \\
\hline $\mathrm{pH}$ & 0,82 & & & & & 0,72 \\
\hline Ek.Mg & 0,68 & & & & & 0,59 \\
\hline Ek.Zn & & 0,87 & & & & 0,81 \\
\hline Ek.Cu & & 0,78 & & & & 0,73 \\
\hline Ek.Fe & & 0,77 & & & & 0,70 \\
\hline Kum & & & 0,92 & & & 0,87 \\
\hline Silt & & & $-0,92$ & & & 0,86 \\
\hline OM & & & & 0,86 & & 0,77 \\
\hline TN & & & & 0,77 & & 0,74 \\
\hline Ek.K & & & & & 0,82 & 0,78 \\
\hline YP & & & & & 0,72 & 0,74 \\
\hline
\end{tabular}

Ek.Ca: Ekstrakte Edilebilir Kalsiyum; Ek.Mg: Ekstrakte Edilebilir Magnezyum; Ek.Zn: Ekstrakte Edilebilir Çinko; Ek.Cu: Ekstrakte Edilebilir Bakır; Ek.Fe: Ekstrakte Edilebilir Demir; OM: Organik Madde; TN: Toplam Azot; Ek.K: Ekstrakte Edilebilir Potasyum; YP: Yarayıșlı Fosfor.

Faktör analizi sonrasında incelenen fiziksel ve kimyasal toprak özellikleriyle ilișkili olarak belirlenen 5 faktörün alansal dağılımlarını ortaya koymak amacıyla yapılan jeoistatistiksel analize ilișkin semivariogram sonuçları Çizelge 6'te, faktörlerin alansal dağılımlarını gösteren krigleme haritaları ise Șekil 3'de verilmiștir. Çizelge 6'da tüm faktörlerin küresel modelle modellendiği görülürken, belirlenen tüm faktörler çalıșma alanı içerisinde güçlü uzaysal bağımlııklar sergilemișlerdir. Camberdella et al. (1994), külçe etkisi/eșik değer oranı $\leq \% 25$ olduğunda uzaysal bağımlıık sınıfını güçlü, \% 25-75 olduğunda orta, $\geq 75$ olduğunda ise zayıf olarak tanımlamaktadır. atanan ekstrakte edilebilir Ca ve Mg'un pH ile pozitif ilișkili olması nedeniyle faktör, bazik katyonlar adıyla tanımlanmıștır. Yıllık ortalama yağıș miktarı 2000 mm'nin üzerinde olan Rize ilinde, bilindiği gibi toprak profildeki bazik katyonların önemli bir kısmı yüksek yağıș miktarıyla yıkanmakta ve sonrasında toprak profilinde asidik katyonlar hakim duruma geçerek toprak pH'sının asidik reaksiyon göstermesine neden olmaktadır. Çalıșmanın yürütüldüğü Karadeniz sahil șeridi ve sahil șeridine yakın çay üretimi yapılan alanlardaki toprakların önemli bir kısmının bazik katyonlarca yetersiz olduğu görülürken, çalıșma alanının kuzeydoğu ve güneybatı kesimlerinin bazı

Çizelge 6. Faktörlere ilișkin semivariogram analiz sonuçları

Table 6. Semivariogram analysis results regarding factors

\begin{tabular}{lcccccccc}
\hline Faktörler & Model & $\begin{array}{c}\text { Külçe } \\
\text { Etkisi }\end{array}$ & $\begin{array}{c}\text { Eșik } \\
\text { Değer }\end{array}$ & $\begin{array}{c}\text { Yapısal } \\
\text { Uzaklık }\end{array}$ & RSS & $r^{2}$ & $\begin{array}{c}\text { Külçe Etkisi/Eșik } \\
\text { Değer Oranı, \% }\end{array}$ & K.B.S. \\
\hline Faktör 1 & Küresel & 0,001 & 0,554 & 7250 & $3,33 \times 10^{-3}$ & 0,982 & 0,18 & Güçlü \\
Faktör 2 & Küresel & 0,084 & 0,792 & 21730 & $2,14 \times 10^{-3}$ & 0,992 & 10,61 & Güçlü \\
Faktör 3 & Küresel & 0,09 & 0,531 & 7870 & $1,12 \times 10^{-3}$ & 0,984 & 16,95 & Güçlü \\
Faktör 4 & Küresel & 0,022 & 0,651 & 5860 & $1,82 \times 10^{-3}$ & 0,989 & 3,38 & Güçlü \\
Faktör 5 & Küresel & 0,001 & 0,836 & 9070 & $9,36 \times 10^{-3}$ & 0,985 & 0,12 & Güçlü \\
\hline
\end{tabular}

RSS: Hata Kareler Toplamı; K.B.S.: Konumsal Bağımlııı Sınıfı

Bileșen olarak ekstrakte edilebilir Ca, Mg ve pH'nın atandığı Faktör 1 toplam değikenliğin \% 18,31'ini açıklamıștır. Faktör l'e bileșen olarak bölgelerinde faktörün pozitif değerler alarak yüksek bulunduğu görülmektedir (Șekil 3). 

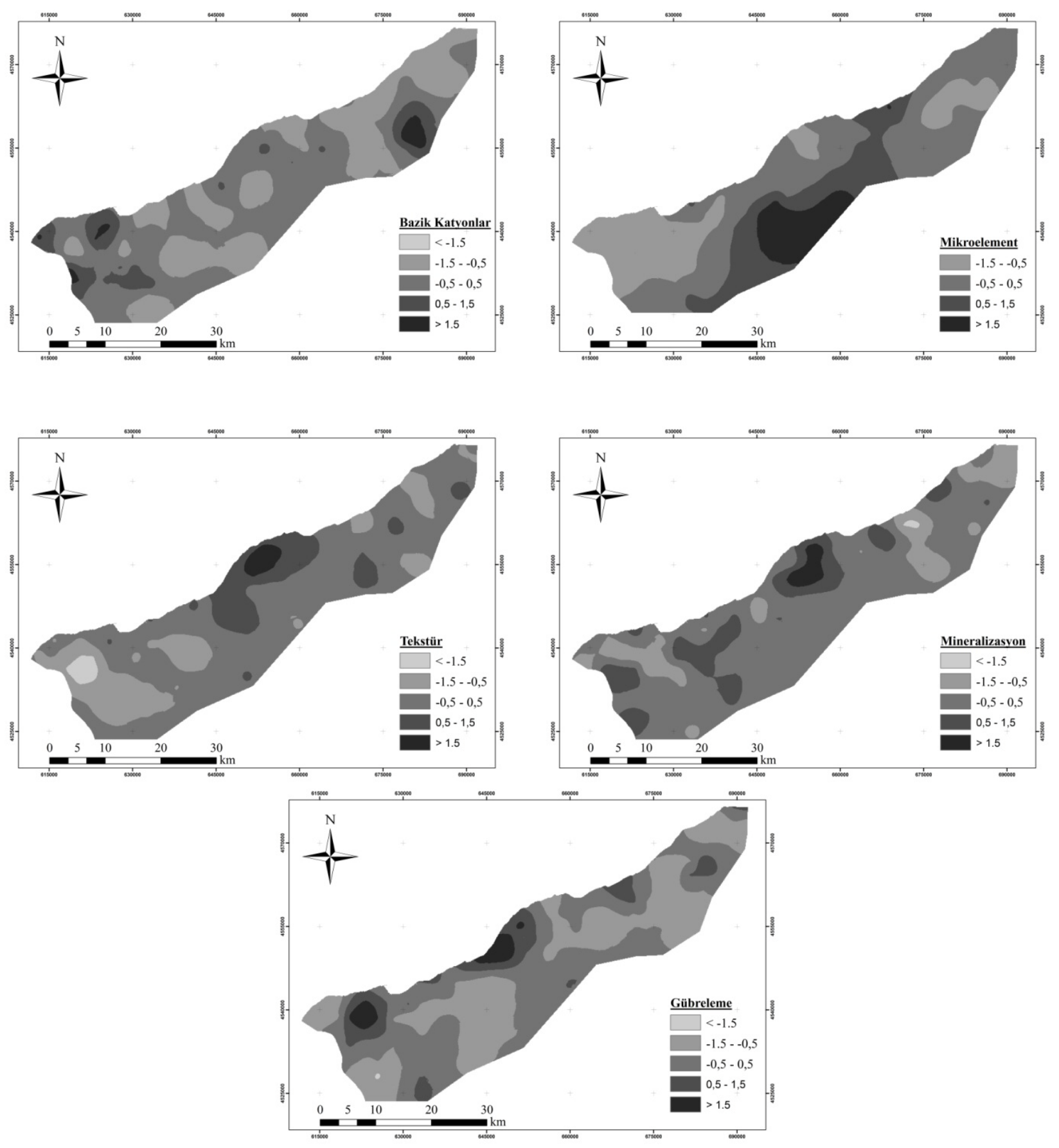

Șekil 3. Faktörlere ait kriging haritaları

Figure 3. Kriging maps for factors

Toplam değișkenliğin \% 17,83'ünü açıklayan ve ekstrake edilebilir Zn, Cu ve Fe'in bileșen olarak atandığı faktör 2'ye mikroelement adı verilmiștir. Faktörün Șekil 3'deki dağıım haritası incelendiğinde, yüksek değerlerini çalıșma alanının orta güney kesimlerinde yer aldığı buna karșın bazik katyonlar faktörünün yüksek değerler aldığı kuzeydoğu ve güneybatı kesimlerinde ise mikroelement faktörünün düșük değerler aldığı görülmektedir. Bu iki faktöre bileșen olarak atanan değișkenler ve faktörlerin alansal dağıımları dikkate alındığında, sonuçların birbirini destekler nitelikte olduğu görülmektedir.

Toprakların kum ve silt içeriklerinin bileșen olarak atandığı faktör 3, toplam değișkenliğin \% 15,98'ini açıklarken, isimlendirmede tekstür adı verilmiștir. Beklenildiği gibi faktör bileșenlerinin ilișkisi negatif bulunurken, faktör bileșeni olarak her iki değișken 
birbirine yakın yük değerleri $(0,92)$ almıș ve faktör analizinde belirlenen faktörler tarafından açıklanabilen oransal etken varyansları da birbirine yakın bulunmuștur (Çizelge 5). Bu durumda tekstür faktöründe kum ve silt içeriğinin etkilerinin eșit veya benzer olduğu söylenebilir. Tekstür faktörü en yüksek değerini orta kuzey kısımda almıș ve bu alanlar kum içeriği yüksek alanlar olarak değerlendirilmiștir. Diğer taraftan faktör en düșük değerini çalıșma alanının güneybatı kesimlerinde alırken, bu alanlarda da toprakların kum içeriklerinin düșük olduğu șeklinde bir değerlendirme yapılmaktadır (Șekil 3).

Toplam değișkenliğin \% 12,62'sini açıklayan faktör 4'e, bileșen olarak atanan organik madde ve toplam N'un özellikle tekstür bileșenleriyle olan korelasyon ilișkileri dikkate alındığında, faktörün mineralizasyon adıyla tanımlanmasının uygun olacağı düșünülmektedir. Korelasyon matriksinde toprakların organik madde içeriği hiçbir tekstür bileșeniyle önemli korelasyonlar göstermezken, toplam N'un kum içeriği $(p<0,01)$ ile pozitif, silt $(p<0,01)$ ve kil içerikleriyle $(p<0,05)$ negatif ilișkili olduğu görülmektedir (Çizelge 3). Yine mineralizasyon faktörünün alansal dağıım haritası da korelasyon ilișkilerine benzer dağılım göstermekte, tekstür faktörünün yüksek değerler aldığı toprakların kum içeriklerinin yüksek, silt ve kil içeriklerinin düșük olduğu bölgelerde, yüksek değerler; toprakların kum içeriklerinin düșük, silt ve kil içeriklerinin yüksek olduğu bölgelerde ise düșük değerler almaktadır (Çizelge 3). Ladd et al. (1981), Ladd et al. (1985), Amato and Ladd (1992), karbon ve azot mineralizasyon oranlarının genelde killi topraklarda kaba bünyeli topraklardan daha düșük olduğunu bildirirken, Kaiser and Guggenberger (2003), bu durumun toprak organik maddesini korumanın temel mekanizması olarak görülen yüzey mineralleri üzerindeki organik moleküllerin sorpsiyonundan kaynaklandığını ifade etmektedir. Çalıșma alanında mineralizasyon ve tekstür faktörlerine ait dağııım desenleri bu araștırmacıların bulgularıyla benzerlikler göstermektedir. Ancak literatürde tekstür ile toprak karbonu arasındaki ilișkiye yönelik bu bulgularla benzer sonuçların yanı sıra, farklı bilgilerde verilmektedir. Quiroga et al. (1996). Hassink (1997), topraktaki karbonunun, toprağın kil ve silt bileșenleriyle çoğunlukla pozitif ilișkili olduğunu ifade ederken; Hassink (1994), topraktaki karbon ile tekstür arasındaki ilișkinin zayıf; Franzluebbers et al. (1996) ve Scott et al. (1996) ise, ilișkinin olmadığını bildirmektedir.
Ekstrakte edilebilir K, ve yarayıșlı P değișkenlerinin bileșen olarak atandığı faktör 5, toplam değișkenliğin \% 10.90'nını açıklarken, daha yüksek yük değeri alan ekstrakte edilebilir $\mathrm{K}$ faktörün daha etkili olan bileșeni olmuștur. Faktör yüksek değerlerini çalıșma alanının orta kuzey ve batı kesimlerinde özellikle Karadeniz sahiline yakın düz alanlarda almaktadır (Șekil 3). Van der Perk (2006), fosfor, potasyum gibi besin elementlerinin topraktaki varlığının kimyasal gübre, ahır gübresi ve atık çamur gibi gübrelerin kullanımıyla değișebildiği bildiriken; Kadereit et al. (2010), artan fosfor içeriklerinin topraklar üzerindeki insan etkilerini gösterdiği ifade etmektedir. Zadorova et al. (2013)'da topraklardaki fosfor ve potasyum varlığının insan etkisinin yanında geçmișteki veya șimdiki erozyonu gösterdiğini ifade etmektedir. Çalıșmanın bulguları incelendiğinde faktör bileșenlerinin tekstür bileșenleriyle önemsiz korelasyon ilișkilerinin bulunması, çalıșma alanındaki ekstrakte edilebilir K ve yarayıș̦ı P'un kaynağının insan kaynaklı bir etki olabileceğini ortaya koymaktadır. Bu nedenle faktöre, insan kaynaklı bir uygulama olan gübreleme adının verilmesinin daha uygun olacağı düșünülmektedir.

\section{SONUÇ}

Çalıșma alanı olarak seçilen Rize ili ülkemizdeki çay üretiminin önemli kısmının yapıldığı bir bölgedir. II, iklim ve toprak özellikleri itibariyle çay bitkisinin gelișimine uygun ortam sağlarken, yapılan bu çalıșma ile çay üretim alanlarında toprak özelliklerinin bireysel değerlendirilmesi yerine toprak özelliklerinin birbirinden bağımsız ortak etkileșimlerini yansıtan daha az sayıda değișkenin belirlenmesi amaçlanmıștır. Yapılan faktör analizi sonrasında incelenen toprak özellklerine ait toplam varyansın \% 75,63'ünü açıklayan 5 faktör belirlenirken, bazik katyonlar adı verilen faktör değișkenlikleri en fazla açıklayan faktör olmuștur. Özyazıcı ve ark. (2013), ülkemizin çay plantasyonlarının yer aldığı Doğu Karadeniz Bölgesi'ndeki tarım topraklarının 19582011 yılları arasındaki toprak asitliğindeki değișimi incelendiğinde; geçen yaklașık 53 yıllık zaman sürecinde anılan toprakların $\mathrm{pH}$ değerlerinde iyileșmenin olmadığı, aksine toprakların büyük çoğunluğunun kritik sınır değerinin $(\mathrm{pH}=4,00)$ altına düștüğünü bildirmektedir. Yine araștırmacılar, çay bitkisinin en iyi gelișme gösterdiği 4,50-6,00 pH aralığının altında yer alan $(\mathrm{pH}<4,50)$ toprakların oranı 1960 'lı yıllarda \% 6, 11 iken, günümüze gelindiğinde bu oranın \% 80'lerin üzerine çıktığını, buna karșıllık çay bitkisinin uygun gelișme gösterdiği $\mathrm{pH}=4,50$ 
6,00 aralığındaki toprak örneklerinin oranın 1960'ı yıllarda \% 88,80 iken, 2011 ylına gelindiğinde bu oranın \% 13,74'lere kadar gerilediğini rapor etmișlerdir. Bu veriler bölgede çay üretimi yapılan alanlar için toprak asitleșmesinin önemli bir sorun olduğunu ortaya koyarken, bu çalıșmada da benzer bulgular ortaya konularak toprak reaksiyonundaki değișimleri doğrudan yansıtan bazik katyonlar, çay üretimi yapılan topraklar için en önemli faktör olmuștur. Toprak $\mathrm{pH}$ 'sı $<5,00$ veya $>9,00$ olduğunda Ca ve Mg'un çözünürlülüğü ve bitkiler için yarayıșllığı önemli bir șekilde etkilenmektedir. Bu nedenle buradaki sonuçlar çalıșma alanındaki topraklarda bazik katyonların miktarının artırılması ve toprak pH'sının yükseltilmesine yönelik için yönetim uygulamalarının planlanması gerektiğini ortaya koymaktadır.

Çalıșma alanı toprakları için ikinci önemli faktör olarak belirlenen mikroelement faktörünün, bazik katyonların yüksek değerler aldığı alanlarda düșük değerler alarak mikroelement yarayıș̦ılığının azaldığını açıkladığı görülmektedir. Bu alanlarda yapılacak mikroelement gübrelemelerinde, uygulama yönteminin seçiminde bazik katyonların ve toprak reaksiyonun dikkate alınmasının gübreleme bașarısını mutlaka artıracağı düșünülmektedir. Diğer taraftan tekstür faktörünün en yüksek pozitif ve negatif değerlerini aldığı bölgelerin çalıșma alanı içerisinde geniș alanlar kaplamaması nedeniyle, faktörün sonuçlarına ilișkin, faktör bileșenleri dikkate alınarak, çalıșma alanında yüksek kum ve silt içeriğine bağlı tekstürel sorunlara sahip alanların fazla olmadığı șeklinde bir değerlendirme yapılabilir.

Bölgenin sıcaklık değerleri dikkate alındığında mineralizasyon faktörünün en yüksek değerlerini, tekstür faktörünün yüksek pozitif değerler aldığı yüksek kum içeriğine sahip sahil düzlüklerinde almıș olması nedeniyle, mineralizasyon sürecinin toprak tekstür koșullarıyla yakından ilișkili olduğu düșünülmektedir. Bu değerlendirmeyle ilișkili olarak toprak özellikleri arasındaki korelasyon ilișkileri incelendiğinde, özellikle mineralizasyon faktörünün toplam $\mathrm{N}$ bileșeninin, tekstür faktörünün pozitif bileșeni olan kum içeriği ile $p<0,01$ düzeyinde pozitif, negatif bileșeni silt içeriği ile de $p<0,01$ düzeyinde negatif ilișkiler sergilediği görülmektedir. Çalıșma bulguları arasında yer alan toplam N ile kum içeriği arasındaki pozitif ilișki nedeniyle, özelikle yüksek kum içeriği sayesinde iyi havalanma koșullarına sahip alanlarda topraktaki mineralizasyon sürecinin hızlandığı düșünülmektedir. Yine gübreleme faktörü olarak tanımlanan son faktörün, mineralizasyon faktörünün yüksek değerlere sahip olduğu alanlara yakın bölgelerde en yüksek değerlerini almıș olması nedeniyle, bu alanlardaki topraklar üzerinde insan kaynaklı etkilerin çalıșma alanının diğer bölgelerine daha fazla olduğu düșünülmektedir.

\section{KAYNAKLAR}

Amato M, Ladd J N (1992). Decomposition of 14Clabelled glucose and legume material in soils: properties influencing the accumulation of organic residue $C$ and microbial biomass C. Soil Biology and Biochemistry, 24: 455464. gov.tr

Anonim (2011). Türkiye İstatistik Kurumu. http://www.tuik.

Anonim (2012). http://www.mgm.gov.tr/veridegerlendir me/il-ve-ilceler-istatistik.aspx?m. (Erișim Tarihi: 19 Kasım 2012).

Anonim (2013). Doğu karadeniz turizm master planı (Giresun - Gümüșhane - Ordu - Rize - Trabzon) http://www.dokap.gov.tr/wpcontent/dosya/rapor/Dogu_Ka radeniz_Rapor.pdf (Erișim Tarihi: 16 Nisan 2013).

Anonim (2012). Rize Ticaret Borsası Stratejik Plan 2012 2017.56 sayfa.

Anonymous (1990). Analytical for atomic absorption spectro photometry. Perkin Elmer, Norwalk, Connecticut, USA.

Bray R H, Kurtz L T (1945). Determination of total, organic and available forms of phosphorus in soils. Soil Science, 59: 39-45.

Bremner J M, Mulvaney C S (1982). Nitrogen-total. Chemical and microbiological properties. In: Methods of Soil Analysis, Part II, ASA Agronomy Monograph No 9 (2nd ed), Madison. pp. 595-625.

Camberdella C A, Moormann T B, Novak J M, Parkin T B, Karlen D L, Turco R F, Konopka A E (1994). Field-scale variability soil properties in centralıowa soils. Soil Science Society of America Journal, 58: 1501-1511.

Cengiz D, Kılınç B (2007). Faktör analizi ile 2006 Dünya Kupası'na katılan takımların sıralamasının belirlenmesi. Marmara Üniversitesi I.I. B.F. Dergisi, Cilt XXIII, Sayı 2, 351-370.

Daniels R B, Hammer R D (1992). Soil geomorphology. John Wiley and Sons Inc., Toronto.

Eden T (1976). Tea thirt edition tropical agriculture series Iongman group limited. London.

Franzluebbers A J, Haney R L, Hons F M, Zuberer D A (1996). Active fractions of organic matter in soils with different texture. Soil Biology and Biochemistry, 28: 13671372.

Gee G W, Bauder J W (1986). Particle-sieze analysis. In: A Klute (Eds.), Methods of Soil Analysis, Part I, Agronomy No9, 388-409.

Gökhale N G (1952). Soil and climatic condations for tea. Capital, Assam, 17, 13.

Hair J F, Anderson R E, Tatham R L, Black W C (1998). Multivariate data analysis (5th ed). Macmillan Publishing 
Company, New York.

Hassink J (1994). Effects of soil texture and grassland managements on soil organic $\mathrm{C}$ and $\mathrm{N}$ and rates of $\mathrm{C}$ and $\mathrm{N}$ mineralization. Soil Biology and Biochemistry, 26: 1221-1231.

Hassink J (1997). The capacity of soils to preserve organic $\mathrm{C}$ and $\mathrm{N}$ by their association with clay and silt particles. Plant and Soil, 191: 77-87.

Hendershot $W H$, Lalande $H$, Duquette M (1993). Soil reaction and exchangeable acidity. In: MR Carter (Eds.), Soil Sampling and Methods of Analysis, Canadian Society of Soil Science.

Kacar B (1984). Çayın gübrelenmesi. Çay İșletmeleri Genel Müdürlüğü, Çay-Kur Yayını No: 4, Ankara, p. 356.

Kadereit A, Kühn P, Wagner G A (2010). Holocene relief and soil changes in loesscovered areas of south-western Germany: the pedosedimentary archives of Bretten-Bauerbach (Kraichgau). Quaternary International 222, 96-119.

Kaiser K, Guggenberger G (2003). Mineral surfaces and soil organic matter. European Journal of Soil Science, 54: 219236.

Kalaycı Ș (2010). Faktör analizi. In: Ș Kalaycı (Eds.), SPSS Uygulamalı Çok Değișkenli İstatistik Teknikleri, Asil Yayın Dağıım Limited Șirketi, Ankara. pp. 321-331.

Ladd J N, Oades J M, Amato M (1981). Microbial biomass formed from $14 \mathrm{C}$ and $15 \mathrm{~N}$-labelled plant material decomposing in soil in the field. Soil Biology and Biochemistry, 13: $119-126$

Ladd J N, Amato M, Oades J M (1985). Decomposition of plant material in Australian soil III: residual organic and microbial biomass $\mathrm{C}$ and $\mathrm{N}$ from isotopelabeled legume material and soil organic matter, decomposing under field condition. Australian Journal of Soil Research, 23: 603-611.

Nelson D W, Sommers L E (1982). Total carbon, organic carbon, and organic matter. Chemical and Microbiological Properties. In: Methods of Soil Analysis, Part II, Agronomy No 9, (2nd ed.), Madison, pp. 539-579.

Nelson R E (1 982). Carbonate and gypsum. Chemical and Microbiological Properties. In: Methods of Soil Analysis, Part II, Agronomy No 9, (2nd ed.), Madison, pp. 181-197.

Özyazıcı M A, Dengiz O, Aydoğan M (2013). Cay yetiștirilen tarım topraklarının reaksiyon değișimleri ve alansal dağılımları. Topraksu Dergisi, 2(1): 23-29.

Quiroga A R, Buschiazzo D E, Peinemann N (1996). Soil organic matter particle size fractions in soils of the semiarid Argentinean Pampas. Soil Science, 16: 104-108.

Rhoades J D (1986). Cation exchange capacity. Chemical and Microbiological Properties. In: Methods of Soil Analysis, Part II., ASA and SSSA Agronomy Monograph No 9 (2nd ed), Madison, pp. 149-157.

Scott N, Cole C, Elliott E T, Huffman S (1996). Soil textural control on decomposition and soil organic matter dynamics. Soil Science Society of America Journal, 60: 1102-1109.

Sharma V S, Ranhanathan $\vee(1985)$. The world of tea today. Outlook an Agriculture, 14(1): 35-36

Shukla M K, Lal R, Ebinger M (2006). Determining soil quality indicators by factor analysis. Soil and Tillage Research, 87: 194-204.

Soil Survey Staff (1992). Procedures for collecting soi samples and methods of analysis for soil survey. Soil Survey Invest. Rep. I. U.S. Gov. Print. Office, Washington D.C.

Tatıdil H (2002). Uygulamalı çok değișkenli istatistiksel analiz. Akademi Matbaası, Ankara

Tekeli S T (1962). Çay teknolojisi. Ankara Üniversitesi Ziraat Fakültesi Yayınları 190, Ders Kitapları 64, Ankara Üniversitesi Basımevi, Ankara.

Tekeli S T (1976). Çay yetiștirme, ișleme, pazarlama. Dönüm Yayınları 5, Ankara Basım ve Ciltevi, Ankara.

Ünlükaptan Y (2008). Çok değișkenli istatistiksel yöntemlerin peyzaj ekolojisi araștırmalarında kullanımı. Doktora Tezi, Cukurova Üniversitesi Fen Bilimleri Enstitüsü, Adana.

Van der Perk M (2006). Soil and water contamination from molecular to catchment scale. Taylor and Francis, Leiden.

Webster R (2001). Statistics to support soil research and their presentation. European Journal of Soil Sciences 52: 331 340.

Wilding L P (1985). Spatial variability: It's documentation, accommodation and implication to soil surveys. In: DR Nielsen and J Bouma (Eds.), Soil Spatial Variability, Pudoc, Wageningen, pp: 166-194

Wolf B (1971). The determination of boron in soil extracts, plant materials, composts, manures, water and nutrient solutions. Soil Science and Plant Analysis, 2: 363-374.

Zadorova T, Penizek V, Sefrna L, Drabek O, Mihaljevic M, Volf S, Chuman T (2013). Identification of neolithic to modern erosion-sedimentation phases using geochemical approach in a loess covered sub-catchment of South Moravia, Czech Republic. Geoderma, 195-196: 56-69. 